\title{
MAKNA SIMBOLIK PANTUN DALAM TRADISI MULANG-MULANGKAN PADA MASYARAKAT MELAYU SAMBAS
}

\author{
Ahadi Sulissusiawan \\ FKIP Universitas Tanjungpura Pontianak \\ email: ahadi.sulissusiawan@yahoo.com
}

\begin{abstract}
Abstrak
Penelitian ini bertujuan mendeskripsikan makna simbolik pantun dalam tradisi mulangmulangkan pada masyarakat Melayu Sambas. Tradisi mulang-mulangkan merupakan tradisi Melayu yang berisikan pernyataan dari orang tua mempelai laki-laki dan perempuan untuk menyerahkan anaknya kepada orang tua, keluarga dan kerabat di lingkungannya agar diterima dengan baik. Penelitian ini menggunakan ancangan etnografi dengan menerapkan analisis mengikuti model kerja etnografi yang dikemukakan Spradley. Prinsip analisis ini meneliti simbol dengan melihat konteks dan makna relasional sebuah istilah setempat yang ada dalam pantun dengan kehidupan budaya masyarakat pemilik teks tersebut. Hasil analisis data menunjukkan bahwa istilah setempat Melayu Sambas mengandung makna simbolik di antaranya nasihat tentang pengantin perempuan yang suci, nasihat kepahitan dalam berumah tangga, nasihat untuk kesetiaan dan rela berkorban, nasihat untuk sabar dan tawakal menghadapi hidup, nasihat untuk menyelesaikan masalah dengan mufakat, nasihat untuk rajin shalat dan tidak bermalas-malasan dalam berumah tangga, dan nasihat untuk mengundang ketika anak lahir.
\end{abstract}

Kata kunci: mulang-mulangkan, pantun, makna simbolik, Melayu, perkawinan

\section{SYMBOLIC MEANINGS OF PANTUN IN THE MULANG-MULANGKAN TRADITION IN THE SAMBAS MALAY COMMUNITY}

\begin{abstract}
This study aims to describe symbolic meanings of pantun in the mulang-mulangkan tradition in the Sambas Malay community. The mulang-mulangkan tradition is a Malay tradition through which the parents of the bride and groom hand over the couple to families and relatives to be well accepted. The study employed the ethnographic approach by applying the analysis according to the ethnographic framework by Spradley. The analysis was conducted by investigating symbols based on the contexts and relational meanings of folk terms in pantun in relation to the cultural life of the community possessing the text. The results of the data analysis show that the folk terms in the Sambas Malay community contain symbolic meanings. Some of them are advice on a pure bride, advice on bitterness in family life, advice on loyalty and willingness to sacrifice, advice on patience and trust in God to face life, advice on problem solving through agreement, advice on diligence in saying prayers and not being lazy in family life, and advice on inviting others when a baby is born.
\end{abstract}

Keywords: mulang-mulangkan, pantun, symbolic meanings, Malay, marriage 


\section{PENDAHULUAN}

Sampai hari ini Sambas menyimpan khazanah kearifan pemikiran yang penuh dengan retorika dan estetika dalam berpantun sebagai sebuah tradisi Melayu. Patut dicatat bahwa pantun Melayu Sambas memperlihatkan representasi alam pemikiran orang Melayu di Sambas. Pemikiran cerdas masyarakat Melayu Sambas tentang manusia, alam, dan Tuhan dalam kaitannya dengan nilai-nilai keislaman sebagai ideologi orang Melayu yang dengan gamblang dapat dilihat dalam pantun (Kling, 2008; Hamid, 2011). Ideologi keislaman dalam berpantun merupakan implikasi berkembangnya tradisi keilmuan dan pengajaran Islam di Kesultanan Sambas sehingga membekalkan masyarakatnya dengan pengetahuan keislaman yang luas (Musa, 2003; Mahrus, 2007). Oleh karena itu, pantun Melayu Sambas tidak hanya menghibur dan mendidik, tetapi menyimpan nilai-nilai adab dan akal budi Melayu yang sangat tinggi.

Pantun telah menjadi wahana komunikasi lisan yang halus tanpa menyinggung perasaan orang lain sehingga menjadikan aktivitas berpantun di Sambas sebagai cara berkomunikasi untuk menunjukkan kesantunan dan kemelayuannya. Tidaklah berlebihan jika Winstedt (1969) pernah berhujah bahwa pantun merupakan pancaran pemikiran Melayu yang dapat dikatakan memuat tentang tabiat, pikiran, dan perasaan orang Melayu.

Pantun sebagai komunikasi lisan Melayu mengandung bahasa yang berkias, mendidik, dan menghibur yang sering diujarkan dalam acara perkawinan Melayu.Tidak mengherankan dalam kegiatan perkawinan Melayu pantun sebagai warisan komunikasi lisan nenek moyang orang Sambas menjadi media sosialisasi ajaran tentang budi dan adab yang memuat falsafah keindahan Melayu (Borhan, 2008; Hamid, 2011). Falsafah keindahan yang mengandung makna simbolik un- tuk mengajarkan manusia Sambas dalam mengenal dirinya dalam menjalani kehidupan sebagai makhluk Tuhan.

Keindahan pantun tidak saja dari bunyi dan rima secara retoris, tetapi juga dari segi estetika dalamannya, yaitu makna-makna tersirat yang terkandung di dalam pantun. Makna-makna simbolik pantun kerap menjadi satire dan perumpamaan dalam tunjuk ajar atau nasihat kepada khalayak penikmatnya. Makna simbolik pantun Melayu Sambas ini pula yang kerap muncul dalam pertunjukkan berbalas pantun pada tradisi mulangmulangkan. Makna-makna simbolik ini berasaskan estetika dalaman dengan pemikiran-pemikiran keislaman sebagai falsafah dalam tunjuk ajar Melayu.

Dalam pantun simbol-simbol yang muncul biasanya berbentuk flora dan fauna seputar kehidupan orang Melayu (Daillie, 1988). Sistem simbol berbentuk flora dan fauna menjadi asas penting dalam menunjukkan rasa simpati, empati, dan tunjuk ajar bagi orang Melayu dengan berlandaskan pemikiran keislaman (Borhan, 2008). Kalau di Jawa sistem simbol seperti yang dilaporkan oleh Geertz (1960) dalam sistem kepercayaan, nilai dan upacara yang berkaitan dengan struktur sosial masih dipengaruhi peradaban Hindu. Wujudnya simbol-simbol itu dapat dilihat melalui slamaten. Di samping itu, Geertz membagi struktur sosial di Mojokuto pada tiga subkebudayaan berdasarkan pada agama, seperti Abangan, Santri, dan Priyayi. Geertz juga menyimpulkan bahwa agama merupakan simbol bagi manusia untuk memahami dan menerima hakikat dari kedudukan dan peranannya dalam kehidupan sosial masyarakat.

Douglas (1966) menyatakan realitas kehidupan manusia dinyatakan melalui simbol-simbol kebudayaan mereka. Melalui tulisannya, beliau menganalisis konsep-konsep 'pencemaran' dan 'pantang'. Beliau menjelaskan bahwa 'pencemaran' dan 'pantang' itu memainkan peranan 
penting dalam memelihara kesatuan dalam struktur sosial. Contohnya dalam budaya masyarakat Lele Zaire (Kongo), ada peraturan untuk melindungi diri mereka dari apa yang mereka maksud dengan 'pencemaran', seperti najis besar, darah, kumpulan-kumpulan tentara, susu, pakaian terpakai, dan persetubuhan. Dengan demikian, rakyat dapat melihat perkara yang bertentangan, yaitu sebagai sesuatu yang bisa diterima dan tidak bisa diterima. Dengan kata lain, nilai-nilai moral dan peranan sosial didukung oleh kepercayaan-kepercayaan.

Pandangan Geertz dan Douglas jelas mengisyaratkan bahwa masyarakat dapat melihat dan menafsirkan simbol-simbol yang ada dalam sebuah komunitas akan menjadi pegangan untuk dimaknai dan dipetik hikmahnya bagi kehidupan sosial mereka. Hal ini pula yang terjadi pada pantun Melayu Sambas. Pantun itu sendiri bagi orang Melayu adalah sebuah simbol yang mengandung nilai, keyakinan, dan kepercayaan orang Melayu. Bahkan, simbol-simbol yang muncul dalam pilihan kata sang penutur pantun menjadi tanda untuk mengambil hikmah dan pelajaran bagi kehidupan sosial budaya mereka.

Simbol-simbol yang terkadung dalam pantun ini pula yang harus dieksplorasi berdasarkan perspektif masyarakat Melayu Sambas sebagai penutur dan pemilik pantun. Hal ini sangatlah mudah karena kata-kata di dalam pertuturan pantun itu merupakan simbol yang bisa ditafsirkan dan diinterpretasikan. Hal ini sejalan dengan pandangan Spradley (1997:121) yang menegaskan bahwa semua makna budaya diciptakan dengan menggunakan simbolsimbol. Semua kata yang digunakan oleh informan dalam menjawab pertanyaanpertanyaan adalah simbol-simbol. Cara informan berpakaian adalah simbol, sebagaimana juga ekspresi wajahnya serta gerakan tangannya. Oleh karena itu, simbol ialah objek atau peristiwa apa pun yang menunjukkan pada sesuatu. Semua simbol melibatkan tiga unsur: simbol itu sendiri, satu rujukan atau lebih, dan hubungan antara simbol dengan rujukan. Ketiga hal ini merupakan dasar bagi semua makna simbolik.

Dalam bahasanya Danesi (2004:44) simbol mewakili sumber acuannya dalam cara yang konvensional. Kata-kata pada umumnya merupakan simbol.Tetapi penanda manapun-sesebuah objek, suara, sosok, dan seterusnya-dapat bersifat simbolik. Bentuk salib dapat mewakili konsep "agama kristiani"; tanda berbentuk $\mathrm{V}$ yang tercipta dari jari telunjuk dan tengah dapat mewakili "perdamaian"; putih dapat mewakili "kebersihan", "kesucian"; "kepolosan", dan gelap mewakili "kotor", "ternoda", "tercela". Makna-makna ini dibangun melalui kesepakatan sosial atau melalui saluran berupa tradisi historis.

Simbol itu sendiri meliputi apa pun yang dapat dirasakan atau dialami. Menggigil dapat diartikan dan dapat pula menjadi simbol ketakutan, kegembiraan atau yang lain. Mencengkeramkan gigi, mengerdipkan mata, menganggukkan kepala, menundukkan tubuh, atau melakukan gerakan lain yang memungkinkan, semua dapat merupakan simbol. Setiap masyarakat memiliki cadangan bahan yang tidak terbatas untuk menciptakan simbol (Spradley, 1997:121).

Secara sederhana rantai makna ini oleh Djajasudarma (1999:24) dijelaskan bahwa simbol merupakan unsur bahasa berupa kata, rujukan adalah objek atau hal yang ditunjuk (peristiwa, fakta di dalam dunia pengalaman manusia), dan konsep adalah apa yang ada pada pikiran kita tentang objek yang diwujudkan melalui simbol. Oleh karena itu, Nida (1996:9) menjelaskan bahwa makna sesuatu kata terdiri atas satu set fitur pembeda yang memungkinkan jenis rujukan tertentu melalui simbol yang tertentu sedangkan rujukan itu sendiri merupakan proses penggelaran bagi beberapa entitas, peristiwa, 
dan sebagainya. Walau bagaimanapun, dua ungkapan yang berlainan mungkin digunakan untuk merujuk objek yang samatidak bermakna ungkapan ini mempunyai makna yang sama pula. Misalnya ungkapan morning star dan evening star dapat digunakan untuk menggelar Bintang Kejora, akan tetapi dua ungkapan tersebut tidak mempunyai makna yang sama.

Terdapat hubungan yang sangat rapat antara makna dengan rujukan karena makna memungkinkan rujukan dan oleh sebab melalui penelitian julat rujukan terhadap sesuatu simbol lah, kita biasanya menentukan maknanya. Makna dipelajari dari contoh rujukan bukan saja bagi bahasa ibunda seseorang tetapi juga bagi sebarang bahasa lain yang mungkin dipelajarinya, kecuali jika seseorang itu dididik dalam konteks pembelajaran buatan, yaitu melalui buku teks dan kamus (Nida, 1996: 9).

Hubungan antara sebuah simbol dengan sebuah rujukan adalah unsur ketiga dalam makna. Hubungan ini merupakan hubungan yang berubah-ubah yang di dalamnya rujukan disendikan dalam simbol itu. Jika penyendian itu terjadi maka kita berhenti untuk memikirkan simbol itu sendiri dan memfokuskan perhatian kita pada apa yang dirujuk oleh simbol itu. Ketika mempelajari, kita menganggap kode-kode simbolik kita sebagai sesuatu yang benar dan seringkali memperlakukan kode-kode simbolik itu seolah-olah equivalent dengan apa yang dirujuknya (Spradley, 1997:122).

Kini, secara sederhana kita sudah menjawab pertanyaan tentang sifat dasar makna. Paling tidak menurut James Spradley makna melibatkan simbol dan rujukan. Kita menyebut ini makna referensial. Walaupun penting, makna referensial tidak terlalu jauh mengarahkan kita pada makna suatu kebudayaan. Makna referensial hanya mulai menggores permukaan makna disendikan dalam simbolsimbol yang digunakan oleh masyarakat
(Spradley, 1997:122). Dengan kata lain, makna referensial adalah makna kata yang ada rujukan atau acuan dalam dunia nyata, seperti kuda dan merah (Lyons, 1993:470-473; Chaer, 2003:291).

Satu di antara cara yang digunakan para sarjana untuk membahas lingkup makna yang lebih besar ini adalah dengan membedakan antara makna denotatif dan makna konotatif. Makna denotatif meliputi hal-hal yang ditunjuk oleh kata-kata (makna referensial). Misal tikus merujuk pada seekor binatang pengerat yang berukuran kecil. Makna konotatif meliputi semua signifikansi dari simbol, yang lebih dari arti referensialnya. Tikus mengonotasikan banyak sekali ide-ide sugestif (Spradley, 1997:122-123).

Penjelasan Spradley memperlihatkan hubungan bahasa dan makna budaya menjadi rujukan penting dalam menafsirkan simbol yang muncul dalam kehidupan masyarakat peribumi. Oleh karena itu, Liliweri (2003: 151) mengartikan simbol sebagai sesuatu yang mewakili sesuatu dan frekuensi penggunaannya yang paling tinggi ada dalam bahasa. Bahasa yang digunakan oleh semua komunitas suku bangsa di dunia terdiri atas susunan kata-kata, kata-kata disusun oleh simbol. Maknanya, bahasa merupakan susunan berlapis-lapis dari simbol-simbol itu (baik yang berasal dari bunyi maupun ucapan) dibentuk oleh sebuah kebudayaan sehingga kata-kata maupun bahasa dibentuk pula oleh kebudayaan. Hal ini menunjukkan bahwa bahasa merupakan komponen budaya yang sangat penting dalam memengaruhi penerimaan kita, perilaku kita, perasaan, dan kecenderungan manusia untuk bertindak menanggapi dunia sekeliling. Dengan kata lain, bahasa memengaruhi kesadaran, aktivitas dan gagasan, benar atau salah, moral atau tidak bermoral, dan baik atau buruk.

Bahasa pula yang menjadi kunci penting lahirnya sebuah tradisi lisan 
Melayu, seperti pantun dalam tradisi mulang-mulangkan di Sambas. Tradisi lisan berbentuk pantun ini mengandung simbol-simbol yang memiliki makna untuk mengajarkan orang Melayu mana yang baik dan mana pula yang buruk. Dengan demikian, simbol-simbol dalam pantun sebagai sebuah produk dari bahasa manusia tentu sangat penting untuk diinterpretasikan. Oleh karena itu pula tulisan ini mendeskripsikan simbolsimbol dalam pantun yang digunakan oleh Muhakam (juru bicara) pihak lelaki dan perempuan dalam tradisi mulangmulangkan sebagai satu di antara tahapan penting dalam adat perkawinan Melayu Sambas. Tulisan ini menginterpretasikan makna-makna simbolik pantun yang terdapat dalam tradisi mulang-mulangkan yang identik dengan nasihat-nasihat bagi pasangan yang baru menempuh hidup baru sebagai suami-istri.

\section{METODE}

Penelitian ini menggunakan kaidah analisis kualitatif (Alwasilah, 2008). Menurut Denzin dan Yvona S.L. (2009:2) penelitian kualitatif merupakan fokus perhatian dengan beragam metode dan model kerja yang mencakup pendekatan interpretatif dan naturalistik terhadap subjek kajiannnya. Hal ini berarti bahwa para peneliti kualitatif mempelajari bendabenda di dalam konteks alaminya, yang berupaya untuk memahami atau menafsirkan fenomena dilihat dari sisi makna yang dilekatkan manusia kepadanya. Hal senada juga dikemukakan Sugiyono (2011:7-8) bahwa metode penelitian kualitatif dinamakan metode postpositivistik karena berlandaskan pada filsafat postpositivisme. Metode ini juga disebut sebagai metode artistik karena proses penelitian lebih bersifat seni (kurang terpola) dan disebut sebagai metode interpretatif karena hasil penelitian lebih berkenaan dengan interpretasi terhadap data yang ditemukan di lapangan.

Data penelitian ini adalah pantunpantun yang dituturkan oleh para $\mathrm{Mu}-$ hakam mempelai lelaki dan perempuan dalam tradisi mulang-mulangkan di Desa Sungai Kelambu. Data utama yang dianalisis berjumlah tujuh pantun yang secara khusus mengandung nasihat perkawinan bagi kedua mempelai yang diujarkan para muhakam.

Analisis kualitatif dalam penelitian ini menerapkan empat metode analisis yang paling penting, yakni observasi, analisis teks dan dokumen, wawancara, dan transkripsi (Silverman 1993 dalam Alwasilah 2008:157). Partisipasi observasi dalam penelitian ini dilakukan pada bulan Desember 2011 di Desa Sungai Kelambu, Kecamatan Tebas, Kabupaten Sambas. Penulis mengamati dan menyaksikan secara langsung pelaksanaan tradisi mulang-mulangkan yang dilaksanakan di rumah mempelai perempuan bernama Nurhaliza binti Ambaludin. Kegiatan observasi partisipasi ini merekam secara keseluruhan tradisi mulang-mulangkan dengan kamera digital, handycam, dan $M P 3$ recorder $2 G B$ yang dikenal dengan sebutan Sony ICRecorder.

Secara khas fokus analisis kualitatif dalam penelitian ini menerapkan analisis mengikuti model kerja etnografi yang diasaskan oleh Spradley (1997) yang berprinsip pada keyakinan bahwa budaya dilihat dari kaca mata mereka yang mengamalkannya (emik) dan juga melalui kaca mata pemerhatian yang saintifik (etik). Prinsip Spradley (1997) dalam meneliti simbol dengan melihat konteks dan makna relasional dalam kehidupan budaya masyarakat pemilik teks merupakan cara penulis dalam mendeskripsikan teks-teks lisan berbentuk pantun yang diujarkan para Muhakam dengan menemukan relasi makna budaya dalam masyarakatnya. 


\section{HASIL DAN PEMBAHASAN \\ Tradisi Mulang-Mulangkan}

Dalam masyarakat Sambas, tradisi mulang-mulangkan merupakan sebuah tahapan yang sangat penting dalam adat perkawinan. Mulang-mulangkan merupakan satu di antara tahapan yang harus dilalui dalam melangsungkan perkawinan. Bahasa sederhana tradisi ini ialah acara serah terima, yaitu pihak laki-laki menyerahkan anak laki-lakinya kepada pihak perempuan. Pihak perempuan menyerahkan anak perempuannya kepada pihak lelaki. Pada hakikatnya, adat mulang-mulangkan ini merupakan hal yang sangat penting dan mendasar bila dibandingkan dengan acara-acara adat lainnya dalam perkawinan Melayu Sambas, kecuali pelaksanaan akad nikah yang sudah menjadi ketentuan fikih Islam.

Mulang-mulangkan pada masa lampau biasanya dilaksanakan pada malam hari. Oleh karena itu, disebut malam mulangmulangkan sebagai kelanjutan perayaan perkawinan pada siang hari. Biasanya pelaksanaan mulang-mulangkan dilakukan bakda Isya. Pihak perempuan dan kaum kerabat berkumpul menunggu kedatangan rombongan pihak laki-laki. Kedatangan pihak lelaki ke rumah pihak perempuan disambut dengan meriah oleh sanak kerabat perempuan. Rombongan pihak lelaki memasuki rumah dan menempati posisi duduk secara berseberangan dengan pihak keluarga perempuan di dalam ruang tamu yang disediakan. Rombongan kedua belah pihak biasanya menghadirkan kedua orang tua mempelai lelaki dan perempuan dalam majelis terhormat ini.

Pada malam itu, pihak perempuan menyiapkan segala sesuatunya demi menyambut kedatangan pihak lelaki. Persiapan itu di antaranya menyiapkan jamuan makan dan kue-kue tradisional, seperti kue lapis, juadah mukun (dodol perenggi, dodol nenas, dodol kemili, dodol kundur, dodol sirang dari beras pulut, dan dodol kacang). Mukun ialah sejenis mangkuk kaca bening dan mempunyai kaki. Kue dodol yang disuguhkan dimasukkan ke dalam mukun tersebut. Oleh itu sebabnya, kue dodol itu dinamakan juadah mukun. Kue lapis dan juadah mukun tersebut biasanya disusun dalam baki sejumlah 10 sampai 12 buah.

Dalam tradisi mulang-mulangkan biasanya diwakili juru bicara, baik pihak lelaki maupun perempuan. Juru bicara ini disebut dalam bahasa lokal dengan istilah muhakam. Juru bicara dipilih berdasarkan ketokohan dan kepandaiannya dalam berpantun. Kepiawaian juru bicara berpantun akan menjadikan pihak yang diwakili menjadi bermartabat dan bermaruah karena membawa adat dengan baik. Sang juru bicara menjadi jembatan kedua belah pihak untuk berkomunikasi guna melaksanakan serah dan terima mempelai lelaki dan perempuan sebagai sebuah keluarga baru bagi kedua belah pihak.

Tidak lama setelah berkelakar dan berbincang bermacam-macam hal, acara malam mulang-mulangkan dimulai. Kedua mempelai dikeluarkan dari bilik masingmasing oleh pengasuh atau mak inang. Pengantin laki-laki ada kalanya memakai setelan jas berdasi dan kain lunggi setengah tiang atau menggunakan setelan baju kurung kain lunggi setengah tiang sedangkan pakaian perempuan mengikut atau disesuaikan dengan pakaian pengantin laki-laki. Setelah kedua pengantin pada tempat yang disediakan, dimulailah acara tersebut.

Kedua wakil saling duduk berhadapan, juru bicara (Muhakam) dari pihak laki-laki yang pertama-tama menyampaikan kata maksud dari kedatangan malam tersebut. Tujuan malam mulang-mulangkan, menyerahkan pengantin laki-laki kepada pihak yang mewakili pihak perempuan dan langsung memberikan petuah kepada pengantin laki-laki tentang kehidupan berumah tangga serta tanggung jawab 
sebagai suami. Selanjutnya, juru bicara pihak perempuan membalas ucapan, terlebih dahulu menerima segala penyerahan dan mudah-mudahan segala apa yang telah diamanahkan kepada pihak perempuan dapat kiranya dilaksanakan demi kebagiaan kedua mempelai. Selanjutnya, pihak perempuan menyerahkan pengantin perempuan kepada pihak laki-laki terutama kepada suaminya dan kepada kedua mertuanya untuk dianggap sebagai anak sendiri serta kepada masyarakat desa untuk turut memberikan nasihat mengenai kehidupan berumah tangga bagi pasangan baru ini.

Setelah acara mulang-mulangkan selesai, dilanjutkan dengan bersalam-salaman antara pengantin lelaki dan perempuan kepada kedua orang tua sebelah perempuan dan lelaki serta kepada tetua, sepupu, dan lain-lainnya yang hadir pada majelis adat mulang-mulangkan. Tradisi mulangmulangkan ini ditutup dengan membaca doa bagi keberkahan dan keselamatan pihak lelaki dan perempuan. Kedua mempelai diharapkan dapat menjadi keluarga sakinah, mawadah, dan warahmah.

Dalam acara mulang-mulangkan ini muhakam pihak lelaki dan perempuan menjadi tumpuan dan perhatian semua orang yang hadir. Cara berkata dan pantun yang diucapkan menjadi ukuran kepuasan tamu undangan yang menyaksikan adat mulang-mulangkan. Pantun yang sesuai dengan nasihat yang disampaikan dan permainan rima akan membuat para tamu berseri-seri. Peran pantun dalam menyampaikan nasihat sangat penting. Pantun menjadi puncak-puncak hiburan dan puncak-puncak tunjuk ajar.

Para Muhakam Melayu Sambas ini jika dibandingkan dengan tradisi adat perkawinan Jawa sebanding dengan keahlian pranata adicara dalam menarasikan tuturannya dengan gaya serupa janturan (cerita atau penjelasan yang dituturkan oleh dalang dalam permainan wayang) permainan katanya mengandung gaya bahasa dan stilistika yang memukau (Kadarisman, 2010:124-125; Suwarna, 2009). Kadarisman (2010:140) menganggap pranata adicara (panatacara) memiliki rasa bahasa yang sangat total dan layak disebut sebagai penyair lokal. Panatacara merupakan empu budaya dan empu bahasa yang berjaga memelihara dan mewariskan totalitas langue bahasa Jawa. Dalam tradisi perkawinan Melayu Sambas sang empu budaya dan empu bahasa adalah performa para muhakam berpantun saat menjadi juru bicara atau ketua rombongan dalam menyampaikan sambutan.

\section{Makna Simbolik Pantun sebagai Nasihat dalam Perkawinan}

Tradisi mulang-mulangkan merupakan adab dan budi orang Melayu Sambas dalam bersopan-santun kepada ibu-bapak, mertua, dan sanak keluarga.Tradisi ini juga memperlihatkan adab dan budi Melayu untuk mempererat tali silaturahmi dan komunikasi antarkeluarga sertamasyarakat sekitar dengan cara-cara yang beradab dan berbudi. Kehalusan adab dan akal budi Melayu tradisi mulangmulangkan semakin nyata saat pantun digunakan untuk menunjukkan halus adab dan budi bicara.

Di dalam pantun itu terdapat makna simbolik yang dalam sebagai bahasa tutur yang halus seorang juru bicara saat menyampaikan pesan. Makna simbolik yang terkandung dalam pantun pada tradisi mulang-mulangkan, yaitu: (1) nasihat tentang pengantin perempuan yang suci, (2) nasihat kepahitan dalam berumah tangga, (3) nasihat untuk kesetiaan dan rela berkorban, (4) nasihat untuk sabar dan tawakal menghadapi hidup, (5) nasihat untuk menyelesaikan masalah dengan mufakat, (6) nasihat untuk rajin salat dan tidak bermalas-malasan, dan (7) nasihat untuk mengundang ketika anak lahir. Makna simbolik diuraikan sebagai berikut. 
Pertama, gambaran makna simbolik nasihat tentang pengantin perempuan yang suci tampak pada kutipan pantun berikut.

(1) Pergi ke hilir sungai kelakang bunga di taman kembang melati sudah takdir sudah suratan adik seorang di pujaan hati. (Pordi Sabli, Mulang-mulangkan, 1/12/2011)

Makna simbolik pantun (1) ini dilambangkan dengan istilah setempat kembang melati yang bermakna kecantikan dan kesucian seorang gadis. Kembang melati merupakan bunga yang harum memiliki tekstur yang indah berwarna putih. Warna putih melambangkan kesucian. Dalam konteks menyerahkan pengantin lelaki kepada mertua dalam adat mulangmulangkan pantun ini menggunakan metafora kembang melati.

Dalam masyarakat Melayu Sambas kembang melati dapat direlasionalkan dengan makna simbolik kecantikan dan kesucian seorang gadis. Dalam konteks ini Muhakam berpesan bahwa pengantin perempuan merupakan wanita yang cantik dan menyejukkan hati yang akan mendatangkan kedamaian bagi suami. Dalam hal memilih pujaan hati Muhakam memilih perkataan kembang melati sebagai simbolisme perempuan cantik dan suci yang dapat menentramkan suami (Pordi Sabli dalam Sulissusiawan, 2014).

Pantun ini merupakan petuah $\mathrm{Mu}-$ hakam mengenai takdir kedua pasangan yang berjodoh menjadi pasangan hidup seperti yang disebutnya dalam baris maksud yang pertama.Takdir dalam Islam adalah ketetapan dari Allah s.w.t. yang wajib diyakini karena merupakan rukun iman.Oleh karena itu, perkawinan kedua mempelai atau pengantin merupakan takdir yang sudah tertulis, istilahnya percaya kepada Qadha' dan Qadar adalah setiap sesuatu yang terjadi itu adalah kehendak dan ketentuan Allah (Pordi Sabli dalam Sulissusiawan, 2014).
Kedua, gambaran makna simbolik nasihat kepahitan dalam berumah tangga tampak pada kutipan pantun berikut.

(2) Paik-paik buah periye kiriman teman dari kartiase baik-baik dengan mertue semoge hidup aman dan sempurne (Pordi Sabli, Mulang-Mulangkan, 1/12/2011)

Pantun (2) ini merupakan ucapan muhakam pihak lelaki saat menasihati pengantin lelaki ketika hendak diserahkan kepada mertua atau orang tua baru si lelaki.Muhakam menggunakan citra buah peria sebagai sayuran yang ditanam orang-orang Melayu. Peria merupakan tumbuhan menjalar, bunganya kecil-kecil berwarna kuning hampir serupa dengan bunga mentimun, buahnya seperti mentimun mempunyai permukaan kulit yang tidak licin, berbintil-bintil kecil, agak pahit rasanya, daunnya berwarna hijau dan bergerigi. Walaupun pahit masih banyak orang Melayu yang menanam dan memakannya (Pordi Sabli dalam Sulissusiawan, 2014).

Citra buah peria digunakan oleh muhakam untuk menjelaskan bahwa ada hubungan antara peria dengan kehidupan berumah tangga bagi pasangan pengantin baru. Simbol buah peria digunakan bagi menjelaskan bahwa dalam berumah tangga itu memang tidak mudah, banyak halang rintang dan penuh onak duri yang akan dihadapi. Pahit dan getir berumah tangga pasti akan dirasakan seumpama rasa buah peria. Sekalipun pahit kehidupan berumah tangga harus tetap dijalankan. Artinya, sepahit-pahitnya kehidupan dalam berumah tangga itu maka hubungan antara pasangan pengantin dengan mertua sama ada bagi pihak perempuan dan lelaki harus tetap baik-baik. Makna ini sesuai dengan konteks pantun itu diperkatakan (Pordi Sabli dalam Sulissusiawan, 2014). 
Simbol buah peria ini merupakan sebuah nasihat dalam konteks perkawinan bagi pengantin lelaki yang hendak diserahkan kepada mertuanya. Buah peria mencitrakan hubungan antara anak dan mertua. Simbol buah peria ini dalam konteks perkawinan dapat dilihat hubungan antarmakna (relasionalnya) sebagai sebuah makna yang merujuk pada makna pahitnya hidup antara anak bersama mertua (Pordi Sabli dalam Sulissusiawan, 2014).

Walaupun, hubungan itu pahit mestilah membuat seorang anak untuk tidak berperangai buruk sehingga tetap menjaga perangai baik dengan mertua. Ibarat pepatah Melayu Sambas bah getah jatuh ke tanah, artinya kalaulah baik dengan mertua pasti betah berada di rumah. Apalagi buah peria dikirim dari Kartiasa, yaitu satu kawasan yang cukup jauh dari wilayah Tebas (tempat pasangan baru menikah ini berasal). Kartiasa juga sebuah simbol tempat yang semakin menegaskan perlambangan untuk menjalin hubungan baik anak kepada mertua harus tetap terjaga karena sudah jauh-jauh datang ke rumah mertua sehingga menjadi lebih berguna dan tidak sia-sia (Pordi Sabli dalam Sulissusiawan, 2014).

Ketiga, gambaran makna simbolik nasihat untuk kesetiaan dan rela berkorban tampak pada kutipan pantun berikut.

(3) Sahabat karib kami sarankan

pergi berkemah selama sepekan apabila tauhid rasul sudah diikrarkan

perintah Allah jangan dilupakan. (Pordi Sabli, Mulang-Mulangkan, $1 / 12 / 2011$ )

Isi pantun ini mengasaskan bahwa jika kita telah beriman atau mengikrarkan tauhid maka perintah Allah s.w.t. harus dilakukan, jangan meninggalkan perintah Allah apalagi sampai melupakan-Nya. Secara umum konteks pantun ini merupa- kan nasihat Muhakam kepada pengantin untuk bertauhid atau mengesakan Allah dengan terus-menerus penuh pengabdian dan kesetiaan. Dalam pembayang ada perkataan sahabat karib sebagai istilah penduduk setempat yang bermakna sebuah simbolisme pengabdian dan kesetiaan yang diamalkan orang Melayu Sambas. Sama halnya dalam mengesakan atau menauhidkan Allah maka orang Melayu pun harus melakukannya penuh dengan kesetiaan dan rela berkorban karena-Nya (Pordi Sabli dalam Sulissusiawan, 2014).

Simbolisme sahabat karib ini diucapkan Muhakan dalam menasihatkan pengantin dalam konteks acara mulang-mulangkan. Dalam relasional makna sosial dan agama perkataan sahabat karib merupakan simbolisme untuk kesetiaan bagi masyarakat Melayu Sambas. Sahabat karib merupakan simbolisasi kesetiaan sebagaimana pertemanan atau persahabatan yang sangat dekat. Persahabatan yang selalu dihiasi dengan saling pengertian dan rela berkorban karena simbol pertemanan dan persahabatan adalah simbol kesetiaan, persaudaraan, dan kedekatan keluarga (Pordi Sabli dalam Sulissusiawan, 2014).

Begitu pula halnya simbolisme tauhid dalam baris maksud pantun. Istilah tauhid merupakan hal yang paling utama dalam agama Islam, masyarakat Sambas sebagai penganut agama Islam sangat menekankan percaya pada Allah. Secara relasional budaya Melayu Sambas jika akan menikahkan anaknya selalu memulai akad nikah dengan membaca kalimat syahadat atau tauhid yang diucapkan oleh pengantin laki-laki. Secara budaya dan agama ikrar tauhid ini sudah mendarah daging sebagai pengamalan ajaran Islam yang sudah lama dipahami orang Melayu Sambas (Pordi Sabli dalam Sulissusiawan, 2014).

Keempat, gambaran makna simbolik nasihat untuk sabar dan tawakal menghadapi hidup tampak pada kutipan pantun berikut. 
(4) Pulau pandan Nampak melintang burung merpati hinggap di dahan cobaan dan rintangan pastilah datang sabar dan tawakal menghadapi kenyataan.

(Pordi Sabli, Mulang-Mulangkan, $1 / 12 / 2011)$

Makna keseluruhan pantun (4) di atas merupakan nasihat Muhakam kepada pengantin dalam menjalani biduk rumah tangga. Cobaan dan rintangan dalam kehidupan perkawinan dapat datang kapan saja. Untuk menghadapi cobaan dan rintangan dalam perkawinan Muhakam mengingatkan untuk bersabar dan bertawakal menghadapinya. Maksud pantun ini disimbolisasikan Muhakam dalam pembayang yang berbunyi Pulau Pandan nampak melintang. Dalam konteks adat mulang-mulangkan simbolisme Pulau Pandan nampak melintang dapat direlasionalkan maknanya dengan kehidupan pasangan pengantin yang baru menikah pasti menghadapi banyak cobaan dan rintangan dalam hidup berumah tangga. Bahkan, Muhakam pula menggunakan simbolisme burung Merpati dalam baris pembayang kedua untuk menasihati pasangan pengantin yang baru berkawin ini sebagai ibarat sepasang merpati. Burung Merpati dalam pemikiran setempat dipercayai simbol muda-mudi dalam masa bercinta-cintaan sebagai pasangan yang serasi dan harmonis. Oleh karena itu, makna simbolik pantun tersebut ialah kesabaran dan ketawakalan dalam hidup berpasang-pasangan sebagai suami dan istri. Walaupun, halangan dan rintangan itu sangat pahit dan kuat menerpa pasangan pengantin baru ini (Pordi Sabli dalam Sulissusiawan, 2014).

Kelima, gambaran makna simbolik nasihat untuk menyelesaikan masalah dengan mufakat tampak pada kutipan pantun berikut.
(5) Kain kulipat bertingkat-tingkat naik sikaduk menuju kebarat pakat mupakat membawa berkat selamatlah hidup dunia dan akhirat. (Pordi Sabli, Mulang-Mulangkan, 1/12/2011)

Pantun (5) ini bermakna dengan melakukan mufakat atau musyawarah dalam memutuskan suatu perkara secara bersama-sama terutama dalam menempuh kehidupan rumahtangga akan mendapatkan karunia atau manfaat yang membawa pengaruh baik. Dengan harapan mufakat tersebut akan menyelamatkan atau membagiakan kehidupan pasangan pengantin di dunia maupun di akhirat. Pantun ini merupakan nasihat bagaimana cara menyelesaikan masalah dalam rumah tangga yang akan dibina dengan cara mufakat. Istilah asli setempat pakat berarti bermusyawarah atau bermufakat untuk mendapatkan kesepakatan atau persetujuan dalam memutuskan suatu perkara atau permasalahan. Mufakat ini disimbolisasikan dengan kain kulipat bertingkat-tingkat sebagai sebuah simbol kehormatan dalam menyelesaikan segala perkara dan permasalahan yang pelik dan kompleks (Pordi Sabli dalam Sulissusiawan, 2014).

Keenam, gambaran makna simbolik nasihat untuk rajin salat dan tidak bermalas-malasan tampakpada kutipan pantun berikut.

(6) Ikan sapat ikan berduri dapat memukat di tanjung batu jike udah dapat kehendak hati jangan lupa salat lima waktu (Mustafa Munzir, Mulang-Mulangkan, 1/12/2011)

Makna keseluruhan pantun (6) di atas adalah sebuah nasihat kepada pengantin perempuan yang telah mendapatkan pujaan hatinya sehingga resmi menjadi istri dari lelaki yang dikehendakinya. Nasihat itu disampaikan Muhakam ke- 
pada pengantin perempuan untuk tidak meninggalkan salat lima waktu saat adat mulang-mulangkan. Setelah mendapatkan kehendak hati agar tidak malas dan lalai (merasa bodoh) untuk mengerjakan ibadah salat lima waktu. Simbolisme malas dan bodoh diwujudkan oleh Muhakam dalam perkataan ikan sapat.

Dalam konteks adat mulang-mulangkan sang Muhakam sesungguhnya memberikan nasihat kepada pengantin perempuan untuk rajin salat lima waktu dan jangan bermalas-malasan serta berpura-pura bodoh. Oleh karena itu, dalam pembayang muhakam sengaja memilih ikan sepat sebagai pengantar sebagai simbol agar si perempuan lebih paham dengan satir ikan sepat dalam masyarakat Sambas yang bermakna bodoh dan malas (Mustafa Munzir dalam Sulissusiawan, 2014).

Ketujuh, gambaran makna simbolik nasihat untuk mengundang ketika anak lahir tampak pada kutipan pantun berikut.

(7) Kalau Agung Mardiansyah pagi memukat dapat ikan belanak

jangan lupa kau pelihara di air tawar jika Agung Mardiansyah nanti udah nimang anak

mudah-mudahan daan lupak mengundang kite tapung tawar

(Mustafa Munzir, Mulang-Mulangkan, 1/12/2011)

Makna pantun (7) ini mengingatkan pada pengantin laki-laki yang bernama Agung Mardiansyah jika memiliki anak, tidak lupa mengundang yang hadir dalam acara tepung tawar anak yang baru lahir. Anak menjadi harapan Muhakam kepada pasangan pengantin agar nanti dapat dilakukan ritual adat tepung tawar. Mendapat anak atau keturunan disimbolisasikan oleh Muhakam dalam konteks adat mulang-mulangkan dalam menasehati pasangan pengantin melalui pembayang yang berbunyi Kalau Agung Mardiansyah paggi memukat dapat ikan belanak. Artinya, kalau pengantin lelaki pergi dalam peraduan istrinya tentu akan mendapatkan anak. Hal ini dapat direlasionalkan dengan makna simbolisasi istilah asli setempat yang digunakan Muhakam memukat dapat ikan belanak yang berarti meletakkan jaring di sungai untuk mendapatkan ikan. Hal ini sebagai ibarat usaha pengantin lelaki untuk mendapatkan anak dengan memukat istrinya di peraduan tidur. Perkara ini dipertegas oleh Muhakam dengan kata tapung tawar dalam baris maksud. Dalam masyarakat Melayu Sambas tapung tawar dilakukan pada saat si ibu melahirkan anak pertamanya (Mustafa Munzir dalam Sulissusiawan, 2014).

Masyarakat Melayu Sambas melaksanakan adab dengan baik dan sempurna. Pelaksanaan adat mulang-mulangkan dilakukan dengan adab dan budi untuk menghormati dan menghargai banyak pihak. Adab dan budi untuk menghormati ibu bapa, suami-istri, mertua, keluarga mara, tetua kampung, dan masyarakat kampung kebanyakan menjadi pesan dari tradisi mulang-mulangkan.Tidak mengherankan pantun diibaratkan layaknya alam semesta. Ia mengandung lebih banyak makna dari apa yang diucapkan. Keberadaan pantun selama berabad-abad sebagai model ekspresi puitis yang terpopuler dan tersebar luas, di antara bentukbentuk lainnya telah menjadi bukti nyata akan keintelektualan dan keartistikan kehidupan masyarakat Melayu, dari rasa keindahan dan kepekaan mereka secara umum merupakan sebagai warisan falsafah dan pemikiran orang Melayu (Daillie, 1988:131-151).

Budi menentukan penghidupan orang Melayu sejak lama dahulu. Melalui pengalaman dan penyesuaian dengan alam sekitar budi Melayu terangkum dalam satu keseluruhan penghidupan mereka. Tradisi mulang-mulangkan merupakan perwujudan adab dan akal budi Melayu di Sambas. Oleh sebab itu, tradisi mulang- 
mulangkan ibarat budi yang sangat dipandang tinggi dan dihormati. Hal ini selari dengan yang diungkapkan Kling (1995:1) menegaskan bahwa rupa dan paras jiwa orang Melayu berbentuk budi dan budi merupakan struktur batiniah Melayu yang terpancarkan dari satu hikmah yang tertinggi (Tuhan). Bahkan, Selat dan Zainal Abidin Borhan (1995:6) menyatakan bahwa budiman dalam masyarakat Melayu sebagai berhati mulia, berakal, bijaksana, beradat, beradab, tahu membalas budi, cukup ajar, dan sebagainya. Bagi mereka manusia budiman melambangkan "a total personality, a perfect gentleman".

\section{SIMPULAN}

Pantun bagi masyarakat Sambas merupakan satu ciptaan piawai seorang $\mathrm{Mu}-$ hakam (juru bicara) dalam menyampaikan sambutan dalam tradisi mulangmulangkan. Walaupun dicipta oleh individu tetapi pantun bukan milik individu, pantun milik kolektif seluruh masyarakat. Lantaran itu, segala wawasan dan nasihat yang terkandung ditujukan kepada semua. Dengan demikian, pantun menjadi alat masyarakat Melayu Sambas untuk mengonstruksi dan mereproduksi kebudayaannya.

Mulang-mulangkan merupakan satu di antara tahapan yang ada dalam upacara perkawinan masyarakat Melayu Sambas yang sangat sakral, baik bagi yang bersangkutan maupun bagi anggota kerabat kedua belah pihak yang akan melaksanakan adat ini. Dalam proses pelaksanaannya harus memperhatikan serangkaian aturan atau tata cara yang biasanya sudah ditentukan secara adat dan bersendikan hukum-hukum agama.

Hasil penelitian menunjukkan bahwa banyak pesan atau nasihat perkawinan yang disampaikan oleh seorang $\mathrm{Mu}$ hakam kepada pasangan yang baru menikah melalui kata-kata yang dituturkan dalam pantun. Dalam penelitian ini ada tujuh nasihat yang disampaikan para
Muhakam (juru bicara) kepada pasangan yang baru menikah.

Pertama, makna simbolik nasihat tentang sosok pengantin perempuan yang suci. Makna simbolik ini diinterpretasi berdasarkan simbol dalam pantun yang memuat pilihan kata kembang melati.

Kedua, makna simbolik nasihat kepahitan dalam berumah tangga. Makna ini disimbolisasikan melalui pilihan kata buah peria yang dalam makna relasional budaya masyarakatnya berhubungan dengan makna kepahitan dan kegetiran hidup.

Ketiga, makna simbolik nasihat untuk kesetiaan dan rela berkorban. Makna ini disimbolisasikan Muhakam sebagai penutur pantun dalam kata sahabat karib. Artinya pasangan yang baru menikah harus setia dan rela berkorban dalam mengarungi kehidupan berumah tangga.

Keempat, makna simbolik nasihat untuk sabar dan tawakal menghadapi hidup. Makna simbolik ini disimbolisasikan melalui frasa Pulau Pandan nampak melintang. Frasa ini dapat direlasionalkan maknanya dengan kehidupan pasangan pengantin yang baru menikah pasti menghadapi banyak cobaan dan rintangan dalam hidup berumah tangga.

Kelima, makna simbolik nasihat untuk menyelesaikan masalah dengan mufakat. Makna simbolik ini disimbolisasikan melalui kata pakat dengan menghubungkannya dengan frasa kain kulipat bertingkattingkat sebagai sebuah simbol kehormatan dalam menyelesaikan segala perkara dan permasalahan yang pelik dan kompleks dengan jalan mufakat.

Keenam, makna simbolik nasihat untuk rajin shalat dan tidak bermalas-malasan. Makna simbolik ini disimbolisasikan melalui kata ikan sapat. Satir ikan sepat dalam masyarakat Sambas bermakna bodoh dan malas.

Ketujuh, makna simbolik nasihat untuk mengundang ketika anak lahir. Makna simbolik ini tersirat dalam frasa 'Kalau Agung Mardiansyah paggi memukat 
dapat ikan belanak'. Artinya, kalau pengantin lelaki pergi dalam peraduan istrinya tentu akan mendapatkan anak. Dengan demikian, jika pasangan pengantin yang sudah resmi suami-istri ini diingatkan untuk mengundang tamu undangan yang hadir untuk kegiatan adat tepung tawar sebagai ritual menyambut anggota baru bagi pasangan yang baru menikah.

\section{UCAPAN TERIMA KASIH}

Penelitian ini bagian dari subbab tesis doktoral tahun 2014 di Universiti Malaya, Kuala Lumpur. Untuk itu, ucapan terima kasih kepada para penyelia Prof. Madya Dr. Zahir Ahmad, Prof. Dato' Dr. Yaacob Harun, dan Prof. Dato' Zainal Abidin Borhan yang telah memberikan arahan, masukan, dan saran yang baik, logis, dan ilmiah dalam penelitian ini.

\section{DAFTAR PUSTAKA}

Alwasilah, A. Chaedar. 2008. Pokoknya Kualitatif. Jakarta: PT Dunia Pustaka Jaya.

Borhan, Z.A. 2008. "Pengungkapan Kosmologikal dalam Pantun Melayu". Dalam Pantun Warisan Rakyat. Kuala Lumpur: Jabatan Kebudayaan dan Kesenian Negara, Kementerian Perpaduan, Kebudayaan, Kesenian dan Warisan Malaysia.

Chaer, A. 2003. Linguistik Umum. Jakarta: Rineka Cipta.

Daillie, F-Rene. 1988. Alam Pantun Melayu: Studies on The Malay Pantun. Kuala Lumpur: Dewan Bahasa dan Pustaka.

Danesi, M. 2004. Pesan, Tanda, dan Makna. Diterjemahkan oleh Evi Setyarini dan Lusi Lian Piantari. Yogyakarta: Jalasutra.

Denzin, N.K. dan Yvona S.L. (Ed.). 2009. Handbook of Qualitative Research. Yogyakarta: Pustaka Pelajar.

Djajasudarma, F. 1999. Semantik 1: Pengantar ke Arah Ilmu Makna. Refika Aditama: Bandung.
Douglas, M. 1966. Purity and Danger: An Analysis of Concepts of Pollution and Taboo. Routledge \& Keegan Paul, London.

Geertz, C. 1960. The Religion of Java. New York: The Free Press.

Hamid, Ungku Abdul Aziz Ungku Abdul. 2011. Pantun dan Kebijaksanaan Akal Budi Melayu. Kuala Lumpur: Dewan Bahasa dan Pustaka.

Kling, Z. 1995. "Manusia Melayu, Alam dan Tamadunnya" dalam Hari Sastera, Melaka.

Kling, Z. 2008. "Pantun dan Keagamaan" dalam Pantun Warisan Rakyat. Kuala Lumpur: Jabatan Kebudayaan dan Kesenian Negara, Kementerian Perpaduan, Kebudayaan, Kesenian dan Warisan Malaysia.

Liliweri, A. 2003. Makna Budaya dalam Komunikasi Antarbudaya. Yogyakarta: LkiS.

Lyons, J. 1993. Pengenalan Linguistik Teoretis. Penerjemah Abdullah Hassan, Rogayah Abdul Razak, dan Wan Zailena Mohd. Noordin. Lumpur: Dewan Bahasa dan Pustaka.

Mahrus, E. 2007. "Menelusuri Akar Historis Pendidikan Islam di Sambas". Dalam Yusriadi (Ed.) Sejarah Islam di Kalimantan Barat. Pontianak: STAIN Press.

Musa, P.H. 2003. Sejarah Kesultanan Sambas Kalimantan Barat: Kajian Naskah Asal Raja-Raja dan Salsilah Raja Sambas. Pontianak: STAIN Press.

Nida, E.A. 1996. Menerokai Struktur Semantik. Penerjemah Mashudi Kader. Kuala Lumpur: Dewan Bahasa dan Pustaka.

Piah, H. Mat. 1989. Puisi Melayu Tradisional: Satu Pembicaraan Genre dan Fungsi. Kuala Lumpur: Dewan Bahasa dan Pustaka.

Piah, H. Mat. 2007. Pantun Melayu: Bingkisan Permata. Kuala Lumpur: Yayasan Karyawan. 
Selat, N. dan Zainal A.B. 2007. "Pantun Budi: Satu Analisis Nilai". Dalam Pantun Manifestasi Minda Masyarakat. Kuala Lumpur: Akademi Pengajian Melayu, Universiti Malaya.

Spradley, J P. 1997. Metode Etnografi. Diterjemahkan oleh Misbah Zulfa Elizabeth. Yogyakarta: Tiara Wacana.

Sulissusiawan, A. 2014. 'Pantun Muhakam dalam Adat Perkahwinan Melayu
Sambas: Analisis Simbolisme'. Kuala Lumpur: Akademi Pengkajian Melayu Universiti Malaya.

Sugiyono. 2011. Metode Penelitian Kuantitatif, Kualitatif, dan $R \in \mathcal{E}$. Bandung: Alfabeta.

Winstedt, R. O. 1969. A History of Classical Malay Literature. Kuala Lumpur: Oxford University Press. 